\title{
Experimental Helicobacter pylori gastric infection in miniature pigs
}

\author{
T. KOGA, Y. SHIMADA, K. SATO, K. TAKAHASHI, I. KIKUCHI, T. MIURA, \\ T. TAKENOUCHI, T. NARITA and M. IWATA
}

Biological Research Laboratories, Sankyo Co. Ltd, Shinagawa-ku, Tokyo, Japan

\begin{abstract}
An experimental Helicobacter pylori infection in miniature pigs was developed and investigated. Eighteen miniature pigs were inoculated with an $\boldsymbol{H}$. pylori strain that has high virulence in mice at $c .5 \times 10^{10} \mathrm{cfu}$. $H$. pylori infection in miniature pigs was achieved by the administration of agar $1 \%$ in brucella broth with fetal bovine serum $10 \%$ just before inoculation. The bacterial colonisation and distribution were analysed by mapping of viable cell counts in the stomach in pigs of three different ages. The mapping assay was achieved on post-infection day 3 for the 5-day-old and 2-week-old pigs, and between days 41 and 43 for 3-month-old pigs. The highest cell counts were observed in 5-day-old pigs, which averaged $4.9 \times 10^{6} \mathrm{cfu} / \mathrm{g}$ of mucosa $(\mathrm{n}=4)$. The bacteria were colonised mainly in the cardiac and fundus gland region in the 5-day-old and 2-week-old pigs, whereas the colonisation sites did not depend on the region in the 3-month-old pigs. Biopsy assay of the antral mucosa of a 3-month-old pig after $\mathrm{H}$. pylori infection showed that this infection persisted for $>22$ months. Serum antibody against $H$. pylori was detected in the infected pigs but not in the uninfected animal. Immunostaining demonstrated the presence of bacteria on the epithelial surface of the infected pigs. A microscopic finding common to all the infected pigs, focal gastritis with infiltration of lymphocytes detected on the lesser curvature of the stomach, resembled the microscopic appearance in $\boldsymbol{H}$. pylori-infected human patients. These results suggest that miniature pigs might be a suitable model for studying $H$. pylori infection.
\end{abstract}

\section{Introduction}

Helicobacter pylori infection is strongly associated with gastroduodenal diseases [1,2] and has also been linked to gastric carcinoma and lymphoma [3,4]. An appropriate animal model is needed for understanding H. pylori infection and its relationship with these diseases. The animals now considered available for this infection model include pigs [5, 6], monkeys [7], dogs [8], mice [9], gerbils [10], rats [11] and guinea-pigs [12]. As pigs are similar to man in gastric physiology and anatomy [13], the first experimental infection with H. pylori was conducted in gnotobiotic pigs soon after the discovery of this organism in the human stomach [5]. Understanding of the mechanisms of diseases and bacterial virulence factors in the pig infection model has made considerable progress $[14,15]$. Pigs infected

Received 30 April 2001; revised version received 10 Sept. 2001; accepted 17 Sept. 2001.

Corresponding author: Dr T. Koga (e-mail: tekoga@shina. sankyo.co.jp). with $H$. pylori had severe epithelial cell vacuolation and significant reduction of the gastric mucosal surface area [16]. Furthermore, the size of areas colonised by bacteria has been shown to vary and the distribution of bacteria has shown a patchy pattern of infection in the pig model [17]. These studies indicate that among animal models, pigs reproduce the greatest number of the features of the disease associated with $H$. pylori infection in man. However, the size of the animals, cost and handling are all disadvantages.

Miniature pigs have characteristics in common with full-size pigs [18]. Furthermore, like their full-sized relatives, miniature pigs can be endoscoped easily, and it is possible to follow H. pylori-induced pathological changes and the effects of therapeutic regimens in the same animal. As it is easier to maintain and handle miniature pigs than full-sized pigs, these animals are more convenient for observation of the infection. Moreover, the degree of genetic homogeneity has been improved as an experimental animal species. Haring et al. have described the successful production of miniature pigs at Göttingen in Germany [19]. CSK 
miniature pigs were originally derived from Göttingen miniature pigs, in a closed colony for 18 years from 1977 to 1994 . However, earlier attempts to colonise $H$. pylori in miniature pigs were unsuccessful [20]. In this study, experimental $H$. pylori infection was developed in CSK miniature pigs and its characteristics were studied.

\section{Materials and methods}

\section{Animals}

Male specific pathogen-free (SPF) CSK miniature pigs (CSK Research Park, Nagano, Japan) were used in this study. The pigs were confirmed to be free of the following common porcine pathogens: Mycoplasma spp., Bordetella spp., Haemophilus spp., Pasteurella multocida and Salmonella spp. Pigs aged 2 days (body weight $550 \mathrm{~g}$ ), 11 days (body weight $1350 \mathrm{~g}$ ) and 11 weeks (body weight $10 \mathrm{~kg}$ ) were purchased and housed individually in suitably adapted cages in the animal facility in a 12-h light-dark controlled room. A constant temperature of $22-25^{\circ} \mathrm{C}$ and humidity of c. $55 \%$ was maintained in the facility. The 2- and 11day-old miniature pigs were inoculated with $H$. pylori after an acclimatisation period of 3 days and the 11week-old miniature pigs were inoculated after an acclimatisation period of 2 weeks. To feed the animals age-suitable standard diets, the following specifically formulated diets were used: Weanylobulin (Nihon Nosan Kogyo KK, Kanagawa, Japan), a milk-based diet given three times daily for the 2-day-old animals; Weanymashace (Nihon Nosan Kogyo KK), a grainbased diet given twice daily for the 11-day-old animals; and combination diets of NS and Lucerne pellet (NS:Lucerne Pellet $=4: 1$; Nisseiken, Tokyo, Japan) given once daily for the 11-week-old animals. Sixweek-old SPF BALB/c (nu/nu) athymic nude mice and 4-week-old SPF outbred ddY mice (Nippon SLC, Shizuoka, Japan) were used in this study. The mice were housed in a 12-h light-dark controlled room, and fed a normal commercial pellet diet (F-2; Funabashi Farms, Chiba, Japan). Drinking water was freely available to all animals. All animal experiments were performed according to the guidelines provided by the Institutional Animal Care and Use Committee of Sankyo Co. Ltd.

\section{Helicobacter spp. status and histological evaluation of the pig herd}

As gastric colonisation with Helicobacter spp. has been reported in domestic pigs [21,22], the presence or absence of gastric Helicobacter spp. in the miniature pigs was ascertained before admission to the study. Ten 3 -month-old miniature pigs were kept for 2 months in the animal facility of this institution. The 16 tissue sections (sites 1-16) shown in Fig. 1 were taken from 10 5-month-old miniature pigs and two 2-week-old miniature pigs and tested by bacterial culture. The

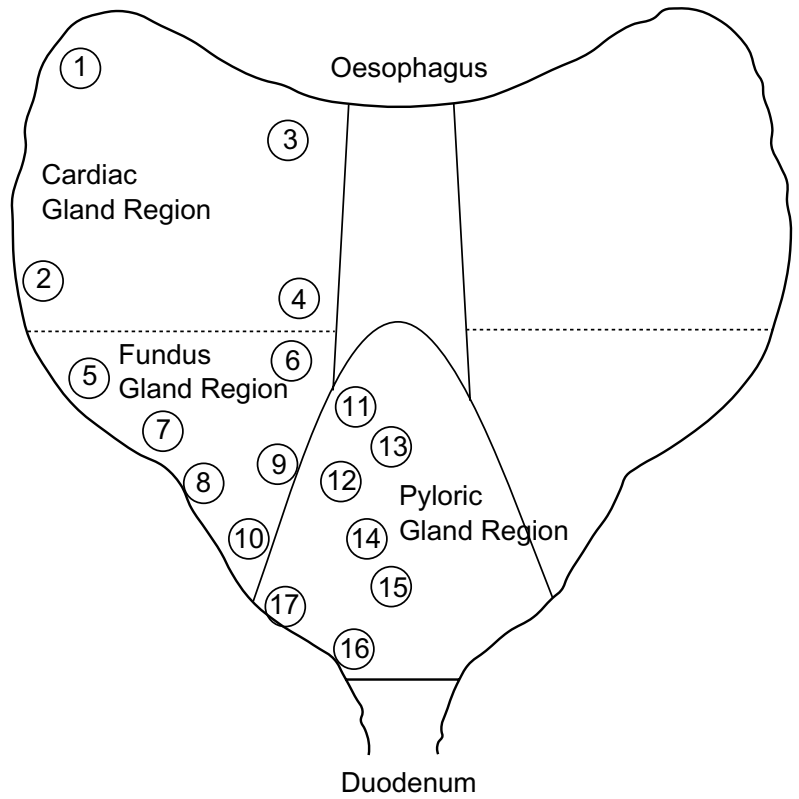

Fig. 1. Sites of biopsy for culture. The stomach was cut open along the greater curvature.

culture methods used have been described previously [23]. Sixteen tissue sections from sites opposite those sampled for culture were immunostained by the method described below. Four tissue sections were taken from the cardiac gland regions of 12 pigs for PCR analysis. DNA was extracted from the tissue sections as described previously [24]. PCR was performed with primers that amplify the urease $\mathrm{B}$ gene of $H$. pylori and $H$. heilmannii [25]. PCR was performed as described previously [25], and PCR products were separated on an agarose $1 \%$ gel and visualised by ethidium bromide. The same sections used for immunostaining were stained with haematoxylin and eosin and examined by light microscopy.

\section{Bacterial inocula}

H. pylori strain no. 9839 used in this study was isolated from gastric biopsy samples from a patient with gastric ulcer. H. pylori no. 9839 was kindly supplied by Dr T. Fujioka (Oita Medical University, Oita, Japan). This strain had the $\operatorname{cag} A$ gene and vacuolating cytotoxin, as confirmed by PCR amplification with primers specific for $\operatorname{cag} A$ and cytotocity assay, respectively [26, 27]. $H$. pylori 26695 is cagA and VacA positive [20], colonises neonatal gnotobiotic pigs [5], and was kindly provided by Professor S. Krakowka (Ohio State University, USA). Stock cultures were stored at $-80^{\circ} \mathrm{C}$ in Brucella Broth (Becton Dickinson, Cockeysville, MD, USA) supplemented with fetal bovine serum (FBS Brucella Broth; Dainippon Pharmaceutical, Osaka, Japan) 2\%. Bacteria were cultured in FBS brucella broth on a gyratory shaker at $110 \mathrm{rpm}$ for $40 \mathrm{~h}$ at $37^{\circ} \mathrm{C}$ in microaerobic conditions. The culture was harvested by centrifugation and the cells were suspended in FBS brucella broth to $1 \times 10^{9} \mathrm{cfu} / \mathrm{ml}$. The bacterial cell counts of all inocula were done with Brain Heart 
Infusion Agar (Difco Laboratories, Detroit, MI, USA) supplemented with horse blood 5\%. Plates were incubated at $37^{\circ} \mathrm{C}$ in a GasPak jar (Becton Dickinson) for 5 days with Campy Paks (Becton Dickinson).

\section{Experimental design}

All miniature pigs were rendered temporarily achlorhydric by intramuscular administration of famotidine (Yamanouchi Pharmaceutical, Tokyo, Japan) at $10 \mathrm{mg} / \mathrm{kg}, 0$ and $3 \mathrm{~h}$ before inoculation. All animals except for the 5-day-old subjects were pre-treated with atropine (Tanabe Seiyaku, Osaka, Japan) $0.05 \mathrm{mg} / \mathrm{kg}$, medetomidine (Meiji Seika Kaisha, Tokyo, Japan) $0.08 \mathrm{mg} / \mathrm{kg}$ and butorphanol (Bristol-Myers Squibb KK, Tokyo, Japan) $0.22 \mathrm{mg} / \mathrm{kg}$, and just before inoculation they were anaesthetised with ketamine hydrochloride (Sankyo) $5 \mathrm{mg} / \mathrm{kg}$ intramuscularly. Four experiments were conducted as described below.

Experiment 1. Four pigs aged 3 months were fasted for $24 \mathrm{~h}$ before inoculation. During anaesthesia, animals received $50 \mathrm{ml}$ of bacterial suspension of $1 \times 10^{9} \mathrm{cfu} / \mathrm{ml}$ in FBS brucella broth via a silicone stomach catheter $(4 \mathrm{~mm} \times 120 \mathrm{~cm}$; Japan Medical Supply, Hiroshima, Japan). The pigs were killed 4143 days after infection for mapping of viable cell counts in the stomach.

Experiment 2. Five pigs aged 3 months were fasted for $24 \mathrm{~h}$ before inoculation, and another served as a control. During anaesthesia, $50 \mathrm{ml}$ of FBS brucella agar were administered just before inoculation of $50 \mathrm{ml}$ of bacterial suspension of $1 \times 10^{9} \mathrm{cfu} / \mathrm{ml}$ in FBS brucella broth, to delay gastric emptying. The FBS brucella agar was prepared by adding FBS $10 \%$ to the brucella broth, which was supplemented with BactoAgar (Difco Laboratories) 1\%, autoclaved and cooled to $c$. $50^{\circ} \mathrm{C}$. A syringe was prefilled with the $\mathrm{FBS}$ brucella agar. After gelatinisation at $4^{\circ} \mathrm{C}$, the $\mathrm{FBS}$ brucella agar was injected by force through the catheter into the stomach. The control pig received FBS brucella broth and FBS brucella agar. Four of the infected pigs and the control animal were killed 41-43 days after infection. The remaining infected pig was observed for $>22$ months. Endoscopy was performed as described below.

Experiment 3. Five pigs aged 2 weeks were fasted for $6 \mathrm{~h}$ before inoculation. FBS brucella agar $(10 \mathrm{ml})$ was administered before inoculation of $10 \mathrm{ml}$ of bacterial suspension of $1 \times 10^{9} \mathrm{cfu} / \mathrm{ml}$ in FBS brucella broth via a silicone stomach catheter $(2.67 \mathrm{~mm} \times 40 \mathrm{~cm}$, Japan Medical Supply). The pigs were killed 3 days after infection.

Experiment 4. Four pigs aged 5 days were inoculated as described in Experiment 3 without anaesthesia. The pigs were killed 3 days after infection.
Infection of $B A L B / c$ nu/nu mice, ddY mice and miniature pigs

Bacterial inocula of H. pylori 9839 or H. pylori 26695 were prepared for mice as described previously [28]. The mice were killed 1 week after infection. Two 2week-old miniature pigs were inoculated as described in Experiment 3. The pigs were killed 5 days after infection.

\section{Culture of $H$. pylori from infected miniature pigs}

Before they were killed, the pigs were fasted with free access to water for $18 \mathrm{~h}$. Under deep sedation with atropine, medetomidine, butorphanol and ketamine hydrochloride, they were cut open and their stomachs were removed. The animals were killed by administration of an overdose of sodium pentobarbital (Dainippon Pharmaceutical). The stomach was cut open along the greater curvature, emptied and gently rinsed with saline to remove the stomach contents. Local H. pylori populations were sampled by taking one biopsy (c. $50 \mathrm{mg}$ ) from each of 16 representative sites: four sites from the cardiac mucosa (sites $1-4$ in Fig. 1), six from the fundic mucosa (sites 5-10) and six from the antral mucosa (sites 11-16). The biopsy specimens were homogenised in $2 \mathrm{ml}$ of FBS brucella broth, followed by dilution with the same broth and $100 \mu \mathrm{l}$ volumes of the dilutions were inoculated on to modified Skirrow's agar plates containing vancomycin (Sigma) $10 \mathrm{mg} / \mathrm{L}$, bacitracin (Sigma) $8 \mathrm{mg} / \mathrm{L}$, polymyxin B (Pfizer Pharmaceutical, Tokyo, Japan) $0.25 \mathrm{mg} / \mathrm{L}$, trimethoprim (Shionogi Pharmaceutical, Osaka, Japan) $2.5 \mathrm{mg} / \mathrm{L}$ and amphotericin B (Sigma) $3 \mathrm{mg} / \mathrm{L}$. Plates were incubated at $37^{\circ} \mathrm{C}$ in microaerobic conditions. Bacterial counts were expressed as $\mathrm{cfu} / \mathrm{g}$ of tissue.

\section{Culture of $H$. pylori from infected mice}

Each stomach specimen was homogenised in $2 \mathrm{ml}$ of FBS brucella broth, followed by dilution with the same broth and $100 \mu \mathrm{l}$ volumes of the dilutions were inoculated on to modified Skirrow's agar plates containing vancomycin $10 \mathrm{mg} / \mathrm{L}$, polymyxin B $2.5 \mathrm{U} / \mathrm{ml}$, trimethoprim $2.5 \mathrm{mg} / \mathrm{L}$, nalidixic acid $15 \mathrm{mg} / \mathrm{L}$ and amphotericin B $3 \mathrm{mg} / \mathrm{L}$ [28]. Plates were incubated at $37^{\circ} \mathrm{C}$ under micro-aerobic conditions for 5 days.

\section{Endoscopy and biopsy specimens}

Before endoscopy the pigs were fasted for $18 \mathrm{~h}$. Endoscopy was performed with anaesthesia and a GIF XQ240 Endoscope (Olympus, Tokyo, Japan). Four biopsy specimens (c. $2 \mathrm{mg}$ ) were taken from the antrum as indicated in Fig. 1 (sites 11, 12, 14 and 16). The specimens were homogenised in $2 \mathrm{ml}$ of FBS brucella broth and cultured for $H$. pylori (see above). The numbers of $H$. pylori were counted as described above. The numbers of $H$. pylori in the 
antral mucosa indicated the average of four antral biopsy specimens and were expressed as the mean and SEM.

\section{Histopathological examination}

Tissue samples for histopathology were taken from sites opposite those sampled for microbiology. Samples for histopathological examination was prepared by the method of Shimizu et al. [29]. Specimens were fixed in a cold Carnoy's solution (of ethanol:acetic acid: chloroform, 6:3:1 v:v:v) for $2 \mathrm{~h}$ at $4^{\circ} \mathrm{C}$. After fixation, they were sliced longitudinally at $5-\mathrm{mm}$ intervals and all tissue sections were then dehydrated in absolute alcohol, cleared in xylene and embedded in paraffin. Serial paraffin sections, $3 \mu \mathrm{m}$ thick, were prepared. One slide from each block was stained with haematoxylin-eosin for morphological observation and one was immunostained for $H$. pylori by an indirect immunoperoxidase method. Histopathological findings were evaluated for the presence of lymphocyte aggregates or lymphoid follicles in each section. A lymphocyte aggregate was defined as $>10$ lymphocytes per $\times 400$ field. After rehydration, sections from Carnoy-fixed materials were re-fixed with buffered formalin $20 \%$ for $30 \mathrm{~min}$. Before the application of anti-H. pylori polyclonal antibody (DAKO Japan, Kyoto, Japan), hydrated sections were treated with a trypsin (Sigma) solution (trypsin $0.2 \%, \mathrm{CaCl}_{2} \quad 0.1 \%$ in $0.05 \mathrm{M}$ Tris buffer, $\mathrm{pH} 7.6$ ) at $37^{\circ} \mathrm{C}$ for $10 \mathrm{~min}$. This anti- $H$. pylori polyclonal antibody also reacts with $H$. heilmannii antigen [22]. After washing with $0.05 \mathrm{M}$ Tris-HCl buffered saline $(\mathrm{pH}$ 7.6), the diluted horseradish peroxidase-conjugated anti-rabbit $\mathrm{IgG}$ antibody (DAKO Japan) was added. Antibody binding sites were visualised with 3',3'-diaminobenzidine tetrahydrochloride (Dojindo Laboratories, Kumamoto, Japan) and the sections were counterstained with haematoxylin.

\section{ELISA for H. pylori antibody}

Just before and after infection in 3-month-old pigs, serum samples were collected and frozen at $-20^{\circ} \mathrm{C}$ for the subsequent determination of $H$. pylori antibodies. Serum IgG antibody to $H$. pylori was assayed by means of the enzyme-linked immunosorbent assay (ELISA) with a commercial kit (Helico G, International Reagents, Kobe, Japan) [30]. The serum samples were diluted to 1 in 100. Dilutions of sera were incubated for $1 \mathrm{~h}$ at $37^{\circ} \mathrm{C}$. The secondary antibody, peroxidaseconjugated goat anti-pig IgG (Bethyl Laboratories, Texas, USA) diluted to a concentration of 1 in 1000 in commercial buffer, was applied to the wells for $30 \mathrm{~min}$ at $37^{\circ} \mathrm{C}$, substrate was added for $10 \mathrm{~min}$ and then stopping solution was added. $\mathrm{OD}_{450}$ was recorded with an ELISA plate reader (MR 580; Dynatech Laboratories, Alexandria, VA, USA).
$P C R$ amplification and restriction fragment-length polymorphism (RFLP)

H. pylori were recovered from the 5-day-old, 2-weekold and 3-month-old miniature pigs at necropsy and from the pig observed for 22 months after inoculation, at biopsy. The DNA samples of the recovered H. pylori were used. Primer sequences chosen for amplification were specific for the $H$. pylori flaA gene [31]. PCR was performed as described previously [24], with some modifications. After PCR amplification, $15 \mu \mathrm{l}$ of reaction mixture were removed and incubated at $37^{\circ} \mathrm{C}$ for $2 \mathrm{~h}$, and the fragments were separated on an agarose $3 \%$ gel. The gels were stained with ethidium bromide.

\section{Statistical analysis}

Proportions were compared by Fisher's exact test; $\mathrm{p}$ values of $<0.05$ were considered statistically significant.

\section{Results}

Helicobacter spp. status and histological evaluation of the pig herd

Ten 5-month-old miniature pigs and two 2-week-old miniature pigs examined were negative for Helicobacter spp. by culture. All miniature pigs examined were negative for $H$. heilmannii and $H$. pylori by both immunostaining and PCR. There was no inflammatory response in all 16 tissue sections from the gastric mucosa of 12 pigs.

\section{Effect of agar on infection of 3-month-old miniature pigs}

No $H$. pylori were recovered from any biopsy specimens of four pigs challenged with a bacterial suspension alone. On the other hand, H. pylori were recovered from all five pigs challenged with a bacterial suspension immediately after administration of the FBS brucella agar.

\section{Number of $H$. pylori in the gastric mucosa of miniature pigs}

H. pylori were recovered from all sites in the 5-day-old infected pigs; they were mainly found in cardiac and fundus gland regions (Table 1). The highest number of viable bacteria was $\log _{10} 6.69 \mathrm{cfu} / \mathrm{g}$ in sites 4 and 7 . In all sites tested (1-16), 5-day-old pigs had more bacteria than the other pigs. In 2-week-old pigs, bacteria were mainly found in cardiac and fundus gland regions and the highest number of viable bacteria was $\log _{10} 5.26 \mathrm{cfu} / \mathrm{g}$ in site 4 . On the other hand, in 3month-old pigs, the colonisation sites differed from the other pig groups. Bacteria were predominantly recovered from site 4 in the cardiac gland region, site 5 in 
Table 1. Number of $H$. pylori in gastric regions of miniature pigs

\begin{tabular}{|c|c|c|c|c|c|c|c|}
\hline \multirow{3}{*}{$\frac{\text { Gastric region }}{\text { Cardia }}$} & \multirow{3}{*}{$\frac{\text { Site }}{1}$} & \multicolumn{6}{|c|}{ Mean (SEM) $\log _{10} \mathrm{cfu} / \mathrm{g}$ of tissue - positive cultures/total } \\
\hline & & \multicolumn{2}{|l|}{ 5-day-old } & \multicolumn{2}{|l|}{ 2-week-old } & \multicolumn{2}{|c|}{ 3-month-old } \\
\hline & & $6.47(0.33) \quad 4$ & $4 / 4$ & $4.15(0.61) 4$ & $4 / 5$ & 3.48 & $2 / 4$ \\
\hline & 2 & $6.48(0.50) \quad 4$ & $4 / 4$ & $4.50(0.30) 5$ & $5 / 5$ & $3.91(0.54) 4$ & $4 / 4$ \\
\hline & 3 & $5.76(0.83) 4$ & $4 / 4$ & 3.75 & $2 / 5$ & 2.51 & $1 / 4$ \\
\hline & 4 & $6.69(0.082) 4$ & $4 / 4$ & $5.26(0.14) 5$ & $5 / 5$ & $5.12(0.11)$ & $4 / 4$ \\
\hline \multirow[t]{6}{*}{ Fundus } & 5 & $6.67(0.15) \quad 4$ & $4 / 4$ & $4.84(0.27) 5$ & $5 / 5$ & $4.57(0.45)$ & $4 / 4$ \\
\hline & 6 & $6.50(0.26) \quad 4$ & $4 / 4$ & $4.34(0.29) 5$ & $5 / 5$ & $3.58(0.39)$ & $4 / 4$ \\
\hline & 7 & $6.69(0.19) \quad 4$ & $4 / 4$ & $4.24(0.36) 5$ & $5 / 5$ & $3.31(0.28)$ & $3 / 4$ \\
\hline & 8 & $6.35(0.23) \quad 4$ & $4 / 4$ & $4.40(0.26) 5$ & $5 / 5$ & $3.48(0.52)$ & $3 / 4$ \\
\hline & 9 & $5.80(0.68) \quad 4$ & $4 / 4$ & $4.38(0.44) 5$ & $5 / 5$ & 4.06 & $2 / 4$ \\
\hline & 10 & $5.78(0.68) \quad 4$ & $4 / 4$ & $4.48(0.44) 5$ & $5 / 5$ & 3.37 & $2 / 4$ \\
\hline \multirow[t]{6}{*}{ Antrum } & 11 & $5.66(0.53) \quad 4$ & $4 / 4$ & $3.97(0.03) 3$ & $3 / 5$ & $4.64(0.19)$ & $4 / 4$ \\
\hline & 12 & $5.16(0.55) \quad 3$ & $3 / 4$ & 2.51 & $2 / 5$ & 4.43 & $2 / 4$ \\
\hline & 13 & $4.81(0.24) \quad 4$ & $4 / 4$ & 4.60 & $1 / 5$ & $3.81(0.49)$ & $3 / 4$ \\
\hline & 14 & $3.52(0.24) \quad 4$ & $4 / 4$ & 3.20 & $1 / 5$ & 4.11 & $1 / 4$ \\
\hline & 15 & $4.48(0.66) \quad 3$ & $3 / 4$ & 2.60 & $1 / 5$ & $3.46(0.38)$ & $3 / 4$ \\
\hline & 16 & $4.97(0.74) \quad 3$ & $3 / 4$ & $<2.45$ & $0 / 5$ & 2.46 & $1 / 4$ \\
\hline
\end{tabular}

the fundus gland region and site 11 in the pyloric gland region and the highest number of viable bacteria was $\log _{10} 5.12 \mathrm{cfu} / \mathrm{g}$ in site 4 . For the control pig, no $H$. pylori were isolated from any sites.

\section{Histopathology}

The presence of lymphoid follicle or lymphocyte aggregates is shown in Table 2. No inflammation was present in the antrum regions. All infected pigs had chronic gastritis at site 4 . Focal to diffuse lymphocyte infiltration in 5-day-old and 2-week-old pigs was prominent in the cardiac and fundus gland regions (sites 1, 3, 4, 6, 8 and 9). This inflammation was also detected in cardiac and fundus gland regions (sites 1-4 and 9) in the 3-month-old animals. The histopathological intensity and severity were most pronounced in the 3-month-old infected pigs. Lymphoid follicle formation occurred in both the lamina propria and the submucosa at site 4 in the 3-month-old pig (Fig. 2a) and the lamina propria at site 4 in the 5-day-old pig (Fig. 2b). No gastric epithelial erosions or ulcerations were observed in any of the infected pigs. Lesions of chronic gastritis were not observed in the uninfected control pig. With immunostaining in the 5-day-old infected pig at site $10, H$. pylori were detected on the epithelial surface. No bacteria were detected in the tissues of the uninfected control pig by immunostaining.

\section{Serum anti-H. pylori antibody}

Fig. 3 shows the serum antibody response to $H$. pylori of 3-month-old pigs infected with $H$. pylori and the uninfected control. Anti- $H$. pylori IgG antibody levels from all infected pigs increased at 2 weeks after infection. The anti- $H$. pylori IgG levels continued to rise over the course of the experiment, suggesting that seropositivity correlated with active infection. The uninfected control pig had no antibody response specific for $H$. pylori.

\section{Persistence of colonisation of H. pylori}

Fig. 4 shows the number of $H$. pylori in the antral mucosa of a 3-month-old pig infected with $H$. pylori. Once the pig was infected, the infection persisted for at least 22 months and the bacterial counts recovered from the stomach were constant. No macroscopic gastritis or gastric ulcers were observed in this pig.

\section{RFLP analysis of $H$. pylori}

The identities of the strains of $H$. pylori isolated from the experimentally infected miniature pigs were com-

Table 2. Histopathological findings in miniature pigs infected with $H$. pylori

\begin{tabular}{|c|c|c|c|c|c|c|c|c|c|c|}
\hline \multirow[b]{3}{*}{ Age of pigs (n) } & \multicolumn{10}{|c|}{$\begin{array}{c}\text { Number of pigs with lymphocyte aggregates or lymphoid } \\
\text { follicles at stomach site }\end{array}$} \\
\hline & \multicolumn{4}{|c|}{ Cardia } & \multicolumn{6}{|c|}{ Fundus } \\
\hline & 1 & 2 & 3 & 4 & 5 & 6 & 7 & 8 & 9 & 10 \\
\hline 5 days $(4)^{*}$ & 2 & 1 & 2 & 4 & 1 & 4 & 2 & 3 & 3 & 1 \\
\hline 2 weeks $(5)^{*}$ & 3 & 1 & 5 & 5 & 1 & 4 & 0 & 2 & 2 & 2 \\
\hline 3 months $(4)^{\dagger}$ & 2 & 2 & 2 & 4 & 0 & 1 & 0 & 0 & 2 & 0 \\
\hline
\end{tabular}

* The presence of histological change was assessed at 3 days after infection.

$\dagger$ The presence of histological change was assessed at 41-43 days after infection. 


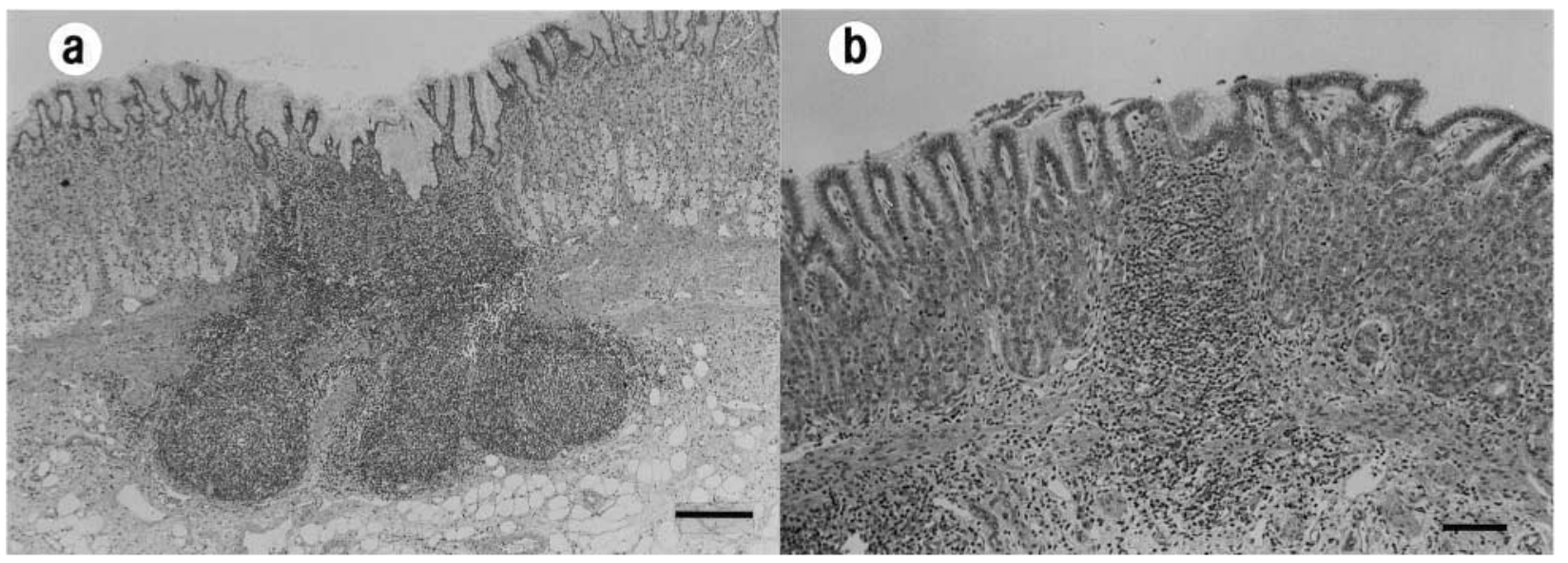

Fig. 2. Lymphoid follicle development in (a) the lamina propria and submucosa of the 3-month-old pig at site 4 (bar $=300 \mu \mathrm{m})$ and (b) the lamina propria of the 5-day-old pig at site 4 (bar $=100 \mu \mathrm{m})$.

pared by RFLP analysis of the $1.5-\mathrm{kb}$ flaA gene segment with that of the infecting strain. The RFLP pattern of the flaA gene PCR product of the infecting strain was virtually identical to that of the strains isolated from the infected miniature pigs (Fig. 5).

Infection of $B A L B / c \mathrm{nu} / \mathrm{nu}$ mice, ddY mice and miniature pigs

To compare the virulence of $H$. pylori 9839 and $H$. pylori 26695 in animals, BALB/c nu/nu mice, ddY mice and miniature pigs were inoculated with each strain. H. pylori 9839 colonised all inoculated mice and the numbers of colonising bacteria in BALB/c nu/ $n u$ and ddY mice averaged $\log _{10} 4.72$ and $4.99 \mathrm{cfu} /$ stomach, respectively (Table 3 ). On the other hand, $H$.

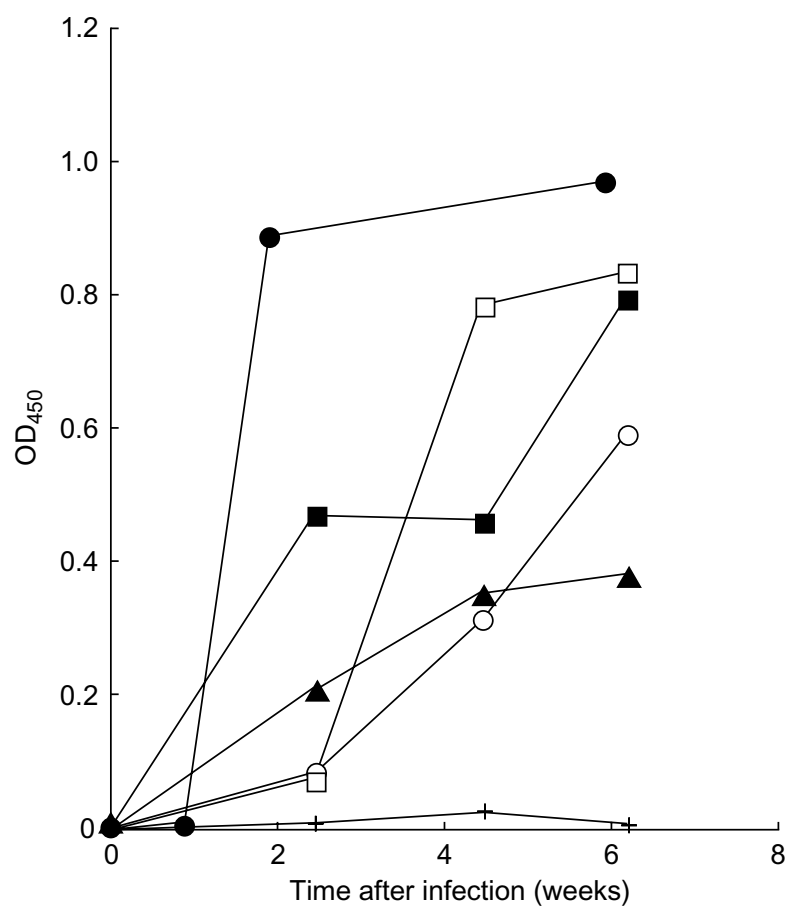

Fig. 3. Antibody response to H. pylori in sera of miniature pigs infected with $H$. pylori $(\bullet, \circ, \mathbf{\square}, \square, \boldsymbol{\Delta})$ and an uninfected pig $(+)$. pylori 26695 was recovered from only one of 15 $\mathrm{BALB} / \mathrm{c} n u / n u$ and $\mathrm{ddY}$ mice $(\mathrm{p}=0.0001)$ and was not recovered from miniature pigs.

\section{Discussion}

Recent studies have reported that spiral shaped gastrospirillum-like organisms (GHLOs) are often found in pigs, especially in slaughterhouse pig stomachs with ulcer or pre-ulcerous lesions in the pars oesophagea [21, 22]. Cloned 16S ribosomal DNA from GHLOs appeared to be very similar to human $H$. heilmannii type 1 [32]. The pre-study results of PCR with $H$. heilmannii and $H$. pylori specific primers and immunostaining suggested that miniature pigs examined in this study were free of $H$. heilmannii and $H$.

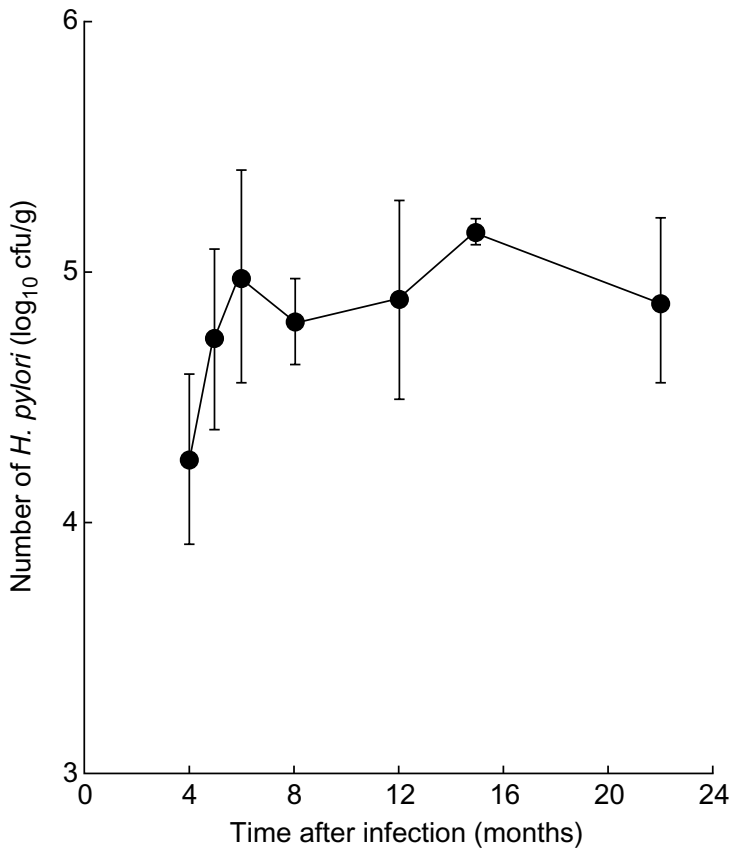

Fig. 4. The number of $H$. pylori in the antral mucosa (mean results from biopsy sites $11,12,14$ and 17; Fig. 1) of the miniature pig infected with $H$. pylori; bar, SEM. 
MboI HhaI HaeIII

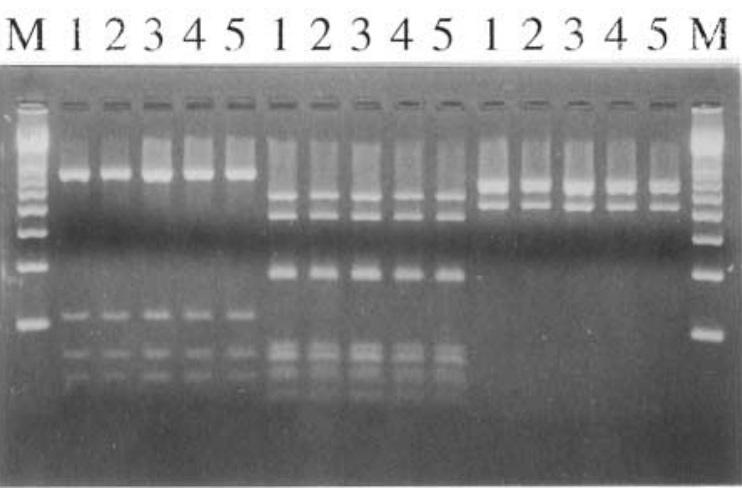

Fig. 5. RFLP analysis of the PCR-amplified $1.5-\mathrm{kb}$ flaA segment of $H$. pylori with the indicated restriction enzymes. Lane 1, PCR product from the infecting strain H. pylori 9839; 2 , PCR products from strains recovered from experimentally infected 5-day-old miniature pigs; 3, PCR products from strains recovered from experimentally infected 2-week-old miniature pigs; 4, PCR products from strains recovered from experimentally infected 3-month-old miniature pigs; 5, PCR products from strains recovered from experimentally infected 3-month-old miniature pigs 22 months after infection; M, 100bp ladder markers (Amersham Pharmacia Biotech, Uppsala, Sweden).

pylori. Moreover, miniature pigs were not infected with other GHLOs, as demonstrated by culturing of gastric tissue samples. Thus, this pig herd was free of gastric Helicobacter organisms. These results are also supported by the observation that non-infected miniature pigs exhibited neither gastritis nor minimal focal gastritis.

These studies have demonstrated that miniature pigs are susceptible to gastric infection with $H$. pylori. Persistent $H$. pylori infection was detected by $H$. pylori culture, systemic immune response and immunostaining of gastric mucosa. The successful chronic colonisa- tion of $H$. pylori in miniature pigs depended on the administration of FBS agar. In a study by Engstrand et al. [6], 8-week-old barrier-born pigs were fed gruel before and after administration of the bacterial suspension, and fat was also injected into the duodenum before bacterial suspension to delay gastric emptying. In the present study, FBS agar was administered into the stomach to delay the passage of the bacterial suspension through the duodenum, with the hope that the prolongation of exposure of the gastric mucosa to the bacteria would make the stomach more susceptible to colonisation with $H$. pylori. Another factor in the successful establishment of $H$. pylori infection was the use of strain no. 9839, a strain that can colonise the stomach of $\mathrm{BALB} / \mathrm{c} n u / n u$ and ddY mice. The colonisation levels of $H$. pylori 9839 in BALB/c $n u /$ $n u$ mice were higher than those of $H$. pylori 2052 [28]. H. pylori 26695 , which can colonise gnotobiotic pigs [5], could not colonise mice and miniature pigs. Strain 9839 may have the ability to colonise several hosts.

The RFLP pattern of the flaA gene PCR product of the infecting strain was virtually identical to those of recovered organisms. This result confirmed the lack of co-infection with other Helicobacter species. The patterns for all five $H$. pylori strains differed from previous reported $H$. pylori strains [24]. RFLP analysis of the $1.5-\mathrm{kb} f l a A$ gene segment with three enzymes, Hae III, MboI and HhaI, would be a useful method to identify the strain.

It is now accepted that $H$. pylori infection is usually acquired early in childhood [33]. However, nothing is known about the factors of age that allow colonisation and distribution of $H$. pylori in the stomach. The present study examined the susceptibility of miniature pigs of different ages to $H$. pylori infection. This is the first evidence that the numbers and distribution of $H$. pylori in the gastric mucosa depend on the ages of the infected miniature pigs. The colonisation levels in the 5-day-old miniature pigs were higher than those in the

Table 3. Experimental infection of $\mathrm{BALB} / \mathrm{c} n u / n u$ mice, ddY mice and miniature pigs with $H$. pylori strains 9839 and 26695

\begin{tabular}{|c|c|c|c|c|}
\hline \multirow[b]{3}{*}{ Animals } & \multicolumn{4}{|c|}{ Bacterial Strain } \\
\hline & \multicolumn{2}{|c|}{ H. pylori 9839} & \multicolumn{2}{|c|}{ H. pylori 26695} \\
\hline & $\begin{array}{l}\text { Number of } \\
\text { infected } \\
\text { animals/ } \\
\text { number } \\
\text { challenged }\end{array}$ & $\begin{array}{c}\log _{10} \mathrm{cfu} / \\
\text { stomach* } \\
\text { or g of tissue }\end{array}$ & $\begin{array}{l}\text { Number of } \\
\text { infected } \\
\text { animals/ } \\
\text { number } \\
\text { challenged }\end{array}$ & $\begin{array}{c}\log _{10} \mathrm{cfu} / \\
\text { stomach } \\
\text { or g of tissue }\end{array}$ \\
\hline $\mathrm{BALB} / \mathrm{c} n u / n u \mathrm{mice}^{+}$ & $15 / 15^{\|}$ & $4.72(0.10)$ & $1 / 15$ & 3.65 \\
\hline ddY mice $*$ & $15 / 15^{\|}$ & $4.99(0.09)$ & $1 / 15$ & 3.50 \\
\hline Miniature pigs ${ }^{\S}$ & $2 / 2$ & 5.50 & $0 / 2$ & $<2.45$ \\
\hline \multicolumn{5}{|c|}{ 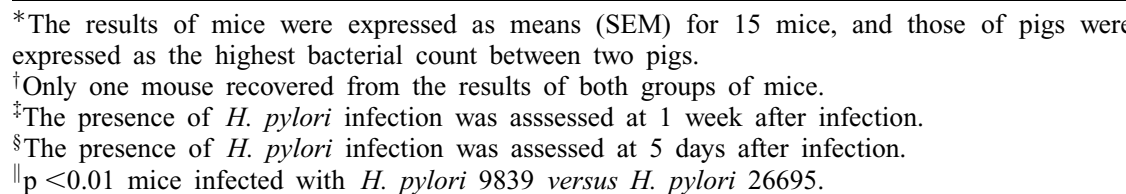 } \\
\hline
\end{tabular}


2-week-old animals and were similar to those of human patients. The reason for the difference in colonisation levels may be due to the age differences in the pigs. However, other factors such as diet cannot be excluded and will have to be investigated by further studies. The colonisation levels in the 5-day-old miniature pigs, 3 days after infection, were also higher than those in the 3-month-old pigs at 41-43 days after infection. This difference in colonisation could be due to the amount of time elapsed.

In 5-day-old and 2-week-old pigs, bacteria were found mainly in the cardiac and fundus gland region, whereas the colonisation sites in the 3-month-old pigs did not depend on the region. However, the site-dependent colonisation observed was similar to that described for man [34]. It has been reported that differences in distribution relate to differences in local acid output in the H. felis-infected mouse model [35]. This difference may be related to the acid output in 5-day-old and 2week-old miniature pigs, which is lower than that in their 3-month-old cohorts. This speculation is supported by the fact that the gastric acid secretory capacity of the pig increases slowly from birth to 4 weeks of age, and that gastric acid secretory capacity at 10 weeks of age is almost equal to that of mature pigs [36]. Five-day-old and 2-week-old pigs may be suitable as models for studying $H$. pylori-infected infants who have low acid output.

The colonisation levels of 5-day-old miniature pigs were comparable to those in gnotobiotic pigs [37]. However, the distribution of bacteria differed between miniature pigs and gnotobiotic pigs in the following respects. Bacterial distribution was predominantly in the cardiac and fundic gland region in miniature pigs but in the cardiac and antrum in gnotobiotic pigs [15]. The reasons for this difference remain unknown. The colonisation levels of 3-month-old miniature pigs were also comparable to those in barrier-born pigs [17]. In the present study, bacteria were predominantly recovered at sites 4, 5 and 11. On the other hand, in barrierborn pigs, sites 4 and 11 gave a positive urease reaction that indicated the presence of $H$. pylori. These findings suggest that this $H$. pylori-infected miniature pig model may be similar to the gnotobiotic and barrier-born pig infection models.

Histopathological examination indicated inflammatory lesions accompanied by lymphoid follicle formation localised in the cardiac and fundus gland regions along the lesser curvature of the stomach. There was a very low number of neutrophils present in the inflamed mucosa. This finding has been demonstrated in several other Helicobacter-infected animal models [9, 11, 12] and comprises the most striking difference between man and animal models. As the sites of inflammation did not always correlate to the sites of bacterial colonisation, the inflammatory response appears to be site-dependent. The absence of any direct correlation between the severity of inflammation and the extent of colonisation was also reported in gnotobiotic pigs [15]. Moreover, in man, the distribution of follicles was unrelated to the intensity of $H$. pylori infection, and lymphoid follicles were more numerous on the lesser than on the greater curvature of the stomach [38]. These findings indicate that the inflammatory response produced following $H$. pylori infection may also depend on the site of stomach affected.

H. pylori were readily observed in the tissue of 5-dayold miniature pigs by immunostaining; bacteria were seen on the epithelial surface. In contrast, organisms were seen only rarely in immunostaining of tissue from 2-week-old and 3-month-old pigs. The number of bacteria at site 10 was $\log _{10} 6.9 \mathrm{cfu} / \mathrm{g}$. Histological detection of bacteria in immunostained sections requires colonisation of $>\log _{10} 6 \mathrm{cfu} / \mathrm{g}$ of tissue. According to Krakowka and Eaton [20], the sensitivity of the Warthin-Starry stain is limited in that H. pylori are identified easily in pigs with a recoverable $\mathrm{cfu}$ $>\log _{10} 6$, with difficulty at $\log { }_{10} 5 \mathrm{cfu}$ and usually as falsely negative below $\log _{10} 4 \mathrm{cfu}$. The sensitivity of immunostaining in the present study would be similar to that of the Warthin-Starry stain.

Most of the infected animals had a detectable specific antibody response to $H$. pylori by 2 weeks after challenge. Seroconversion may take place as early as 1 week after the exposure. A similar antibody response has been observed in several other infected animal models $[11,12]$ but, in man, $\geqslant 3$ weeks may be required to produce a detectable IgG response [39]. This rapid increase in specific IgG may be related to the high oral inoculation dose of $H$. pylori or the severity of colonisation. The uninfected control had no immune response against $H$. pylori, indicating that normal miniature pigs possess no natural cross-reacting antibodies against $H$. pylori.

Once infected, bacteria were recovered from the antrum mucosa at colonisation levels ranging from $\log _{10} 4$ to $5 \mathrm{cfu} / \mathrm{g}$, a range that remained constant throughout the study period (22 months). However, no macroscopic gastritis and gastric ulcer were observed in the infected pig. This observation needs further confirmation with a longer observation period and a larger number of miniature pigs.

In summary, miniature pigs were successfully colonised with $H$. pylori. The numbers and distribution of $H$. pylori in the gastric mucosa depended on the ages of the infected miniature pigs. The 5-day-old and 2-weekold miniature pigs may provide useful models for the study of the infection in human infants and the 3month-old pigs may provide a useful model for the study of the infection in human adults. In conclusion, miniature pigs might be a suitable model for studying the relationship between age and $H$. pylori infection and H. pylori-associated diseases in man. 
We thank M. Hayama, H. Ota and T. Katsuyama of Shinsyu University Hospital for their help with the immunostaining. This study was performed as a project of SLA Research and was supported by grants from SLA Research.

\section{References}

1. Blaser MJ. Gastric Campylobacter-like organisms, gastritis, and peptic ulcer disease. Gastroenterology 1987; 93: 371-383.

2. Calam J. Helicobacter pylori. Eur J Clin Invest 1994; 24: 501-510

3. Parsonnet J, Friedman GD, Vandersteen DP et al. Helicobacter pylori infection and the risk of gastric carcinoma. $N$ Engl $J$ Med 1991; 325: 1127-1131.

4. Parsonnet J, Hansen S, Roudriguez L et al. Helicobacter pylori infection and gastric lymphoma. $N$ Engl J Med 1994; 330: 1267-1271.

5. Krakowka S, Morgan DR, Kraft WG, Leunk RD. Establishment of gastric Campylobacter pylori infection in the neonatal gnotobiotic piglet. Infect Immun 1987; 55: 2789-2796.

6. Engstrand L, Gustavsson S, Jörgensen A, Schwan A, Scheynius A. Inoculation of barrier-born pigs with Helicobacter pylori: a useful animal model for gastritis type B. Infect Immun 1990; 58: $1763-1768$

7. Baskerville A, Newell DG. Naturally occurring chronic gastritis and $C$. pylori infection in the Rhesus monkey: a potential model for gastritis in man. Gut 1988; 29: 465-472.

8. Radin MJ, Eaton KA, Krakowka S et al. Helicobacter pylori gastric infection in gnotobiotic beagle dogs. Infect Immun 1990; 58: 2606-2612.

9. Karita M, Li Q, Cantero D, Okita K. Establishment of a small animal model for human Helicobacter pylori infection using germ-free mouse. Am J Gastroenterol 1991; 89: 208-213.

10. Hirayama F, Takagi S, Yokoyama Y, Iwano E, Ikeda Y. Establishment of gastric Helicobacter pylori infection in Mongolian gerbils. J Gastroenterol 1996; 31 Suppl 9: 24-28.

11. Li H, Kalies I, Mellgard B, Helander HF. A rat model of chronic Helicobacter pylori infection. Studies of epithelial cell turnover and gastric ulcer healing. Scand J Gastroenterol 1998; 33: $370-378$

12. Shomer NH, Dangler CA, Whary MT, Fox JG. Experimental Helicobacter pylori infection induces antral gastritis and gastric mucosa-associated lymphoid tissue in guinea pigs. Infect Immun 1998; 66: 2614-2618.

13. Kurihara-Bergstrom L, Woodworth M, Feisullin S, Beall P. Characterization of the Yucatan miniature pig skin and small intestine for pharmaceutical applications. Lab Anim Sci 1986; 36: $398-399$.

14. Eaton KA, Morgan DR, Krakowka S. Campylobacter pylori virulence factors in gnotobiotic piglets. Infect Immun 1989; 57: $1119-1125$

15. Krakowka S, Eaton KA, Rings DM, Morgan DR. Gastritis induced by Helicobacter pylori in gnotobiotic piglets. Rev Infect Dis 1991; 13 Suppl 8: S681-S685.

16. Bertram, TA, Krakowka S, Morgan DR. Gastritis associated with infection by Helicobacter pylori: comparative pathology in humans and swine. Rev Infect Dis 1991; 13 Suppl 8: S714-S722.

17. Engstrand L, Rosberg K, Hübinette R, Berglindh T, Rolfsen W, Gustavsson S. Topographic mapping of Helicobacter pylori colonization in long-term-infected pigs. Infect Immun 1992; 60: $653-656$.

18. Weaver ME, McKean CF. Miniature swine as laboratory animals. Lab Anim Care 1965; 15: 49-56.

19. Haring R, Gruhn R, Smidt D, Schven B. Miniature swine development for laboratory purposes. In: Bustad LK, McClellan RO (eds) Swine in biomedical research. Battelle Memorial Institute. 1966: 789-796.
20. Krakowka S, Eaton KA. Helicobacter pylori infection in gnotobiotic piglets: a model of human gastric bacterial disease. In: Tumbleson M, Schook L (eds) Advances in swine in biomedical research, vol II. New York, Plenum Press. 1996: 779-810

21. Yeomans ND. Helicobacter heilmannii (formerly Gastrospirillum): association with pig and human gastric pathology. Gastroenterology 1996; 111: 244-259.

22. De Groote D, van Doorn L-J, Ducatelle R et al. 'Candidatus Helicobacter suis', a gastric helicobacter from pigs, and its phylogenetic relatedness to other gastrospirilla. Int $J$ Syst Bacteriol 1999; 49: 1769-1777.

23. Handt LK, Fox JG, Dewhirst FE et al. Helicobacter pylori isolated from the domestic cat: public health implications. Infect Immun 1994; 62: 2367-2374.

24. Fox JG, Batchelder M, Marini R et al. Helicobacter pyloriinduced gastritis in the domestic cat. Infect Immun 1995; 63: 2674-2681.

25. Neiger R, Dieterich C, Burnens A et al. Detection and prevalence of Helicobacter infection in pet cats. $J$ Clin Microbiol 1998; 36: 634-637.

26. Leunk RD, Johnson PT, David BC, Kraft WG, Morgan DR. Cytotoxic activity in broth-culture filtrates of Campylobacter pylori. J Med Microbiol 1988; 26: 93-99.

27. Tummuru MKR, Cover TL, Blaser MJ. Cloning and expression of a high-molecular-mass major antigen of Helicobacter pylori: evidence of linkage to cytotoxin production. Infect Immun 1993; 61: 1799-1809.

28. Koga T, Kawada H, Utsui Y, Domon H, Ishii C, Yasuda H. In-vitro and in-vivo antibacterial activity of plaunotol, a cytoprotective antiulcer agent, against Helicobacter pylori. J Antimicrob Chemother 1996; 37: 919-929.

29. Shimizu T, Akamatsu T, Ota H, Katsuyama T. Immunohistochemical detection of Helicobacter pylori in the surface mucous gel layer and its clinicopathological significance. Helicobacter 1996; 1: 197-206.

30. Sunnerstam B, Kjerstadius T, Jansson L, Giesecke J, Bergström M, Ejderhamn J. Detection of Helicobacter pylori antibodies in a pediatric population: comparison of three commercially available serological tests and one in-house enzyme immunoassay. J Clin Microbiol 1999; 37: 3328-3331.

31. Taylor NS, Fox JG, Akopyants NS et al. Long-term colonization with single and multiple strains of Helicobacter pylori assessed by DNA fingerprinting. J Clin Microbiol 1995; 33: $918-923$.

32. Solnick JV, O'Rourke J, Lee A, Paster BJ, Dewhirst FE, Tompkins LS. An uncultured gastric spiral organism is a newly identified Helicobacter in humans. J Infect Dis 1993; 168: 379-385.

33. Cullen DJE, Collins BJ, Christiansen KJ et al. When is Helicobacter pylori infection acquired? Gut 1993; 34: 1681-1682.

34. Bayerdörffer $\mathrm{E}$, Oertel $\mathrm{H}$, Lehn $\mathrm{N}$ et al. Topographic association between active gastritis and Campylobacter pylori colonisation. J Clin Pathol 1989; 42: 834-839.

35. Danon SJ, O'Rourke JL, Moss ND, Lee A. The importance of local acid production in the distribution of Helicobacter felis in the mouse stomach. Gastroenterology 1995; 108: 1386-1395.

36. Ishii T. Physiology of suckling swine. In: Kashiwazaki M, Kubo M, Kogue E et al. (eds) Disease of swine, 4th edn. Tokyo, Kindai Syuppan. 1999: 41-44.

37. Krakowka S, Eaton KA, Rings DM. Occurrence of gastric ulcers in gnotobiotic piglets colonized by Helicobacter pylori. Infect Immun 1995; 63: 2352-2355.

38. Genta RM, Hamner HW, Graham DY. Gastric lymphoid follicles in Helicobacter pylori infection: frequency, distribution, and response to triple therapy. Hum Pathol 1993; 24: $577-583$

39. Morris A, Nicholson G. Ingestion of Campylobacter pyloridis causes gastritis and raised gastric pH. Am J Gastroenterol 1987; 82: 192-199. 